-Special Edition Central (Japan) Section : New colorant technologies-

\title{
Relationship between Crystal Packing and Solid-State Fluorescence Quantum Yield in Pyrazine Monoboron Complexes
}

\author{
Yasuhiro Kubota*, ${ }^{*}$, Yuki Haishima*, Kazumasa Funabikı* and Masaki Matsui* \\ * Department of Materials Science and Technology, Faculty of Engineering, Gifu University, 1-1 Yanagido, Gifu, Gifu 501-1193, Japan \\ $\uparrow$ Corresponding Author, E-mail: kubota@gifu-u.ac.jp
}

(Received May 26, 2020; Accepted August 17, 2020)

\begin{abstract}
The relationship between crystal packing and solid-state fluorescence quantum yield $\left(\Phi_{\mathrm{f}}\right)$ in pyrazine monoboron complexes $\mathbf{1} \sim \mathbf{6}$ was investigated. The maximum fluorescence wavelength $\left(F_{\max }\right)$ of the $\mathrm{BPh}_{2}$ complexes $\mathbf{4} \sim \mathbf{6}$ was blue-shifted $(524 \sim 628 \mathrm{~nm})$ and the $\Phi_{\mathrm{f}}$ values were higher $(0.13 \sim 0.29)$ than those of the corresponding $\mathrm{BF}_{2}$ complexes $\mathbf{1} \sim \mathbf{3}\left(F_{\max }: 531 \sim 672 \mathrm{~nm}, \Phi_{\mathrm{f}}: 0.04 \sim 0.13\right)$, probably due to inhibition of the intermolecular interactions. Despite weaker intermolecular interactions of the dimethylamino-substituted $\mathrm{BPh}_{2} \mathrm{complex}^{6}$ compared to non-substituted $\mathrm{BF}_{2}$ complex $\mathbf{1}, \mathbf{6}\left(\Phi_{\mathrm{f}}=0.13, F_{\max }=628 \mathrm{~nm}\right)$ had the same $\Phi_{\mathrm{f}}$ value as $\mathbf{1}\left(\Phi_{\mathrm{f}}=0.13, F_{\max }=542 \mathrm{~nm}\right)$ due to red-shifted $F_{\max }$, which promoted non-radiative processes.
\end{abstract}

Key-words: Boron complex, $\beta$-iminoenolate ligand, Pyrazine, Solid-state fluorescence, Crystal packing

\section{Introduction}

Despite the wide-ranging applications of solid-state fluorescent organic dyes in a variety of areas such as organic light-emitting diodes ${ }^{1)}$, solid-state dye lasers ${ }^{2)}$, and organic light-emitting field-effect transistors ${ }^{3)}$, the development of these dyes is still challenging. Common organic dyes that fluoresce in dilute solution often quench or reduce the fluorescence intensity in the solid state; this phenomenon is called aggregation-caused quenching (ACQ) or concentration quenching ${ }^{4)}$. The solid-state fluorescence properties of organic dyes are known to be strongly dependent on the molecular packing ${ }^{5)}$. In many cases, the intermolecular $\pi-\pi$ interactions in the solid state lead to $\mathrm{ACQ}^{6}$. The introduction of bulky substituent group in organic dyes should prevent the formation of intermolecular $\pi-\pi$ interactions and is often used for the expression of fluorescence and enhancement of the fluorescence quantum yield in the solid state ${ }^{7)}$.

Organoboron complexes are some of the most vital fluorescent dyes. Due to the rigid molecular skeleton, organoboron complexes often fluoresce in solution ${ }^{8,9}$. Additionally, the photophysical properties such as absorption and fluorescence wavelengths can be controlled by the type of ligand. However, similar to the common organic dyes, organoboron complexes exhibit the ACQ phenomenon in the solid state. In the course of our studies on the organoboron compounds ${ }^{10-14)}$, we have found that the introduction of

【Figures and illustrations】 Figures and illustrations published in black and white in the journal can be seen in color at our public website $\lceil$ J-STAGE $\rfloor$.

Please make use of it. bulky substituent groups, particularly on the boron atom, is a good strategy for enhancement of the fluorescence quantum yield of organoboron compounds. We have also reported pyrazine monoboron complexes featuring a $\beta$-iminoenolate ligand that show interesting fluorescence properties in solution such as fluorescence solvatochromism ${ }^{15)}$. In this paper, we reported the relationship between crystal packing and solid-state fluorescence quantum yield in the pyrazine monoboron complexes.

\section{Experimental}

The synthesis and fluorescence properties of pyrazine monoboron complexes $\mathbf{1} \sim \mathbf{6}$ in solution were reported in our previous paper ${ }^{15}$. Fluorescence spectra in the solid state were measured with a Jasco FP-8600 spectrofluorometer. Fluorescence quantum yields in the solid state were recorded with a Hamamatsu Quantaurus-QY instrument. The single crystals of $\mathbf{1}, \mathbf{4}$, and $\mathbf{6}$ were obtained by the slow diffusion of hexane into chloroform solutions of the corresponding compounds. Single-crystal X-ray diffraction measurements were performed on a Rigaku Mercury 375R/ M CCD (XtaLAB-mini) diffractometer with graphitemonochromated Mo $\mathrm{K} \alpha$ radiation $(\lambda=0.71075 \AA)$. The crystal structures were solved using direct methods with SHELXS-97 or SHELXS2013 and refined by full-matrix least-squares methods with anisotropic thermal parameters for non-hydrogen atoms on $F^{2}$ using SHELXL-97 or SHELXL2013. All hydrogen atoms were placed using AFIX instructions. The Cambridge Crystallographic Data Center (CCDC) numbers for 1, 4, and $\mathbf{6}$ are 1567751, 1567752, and 
1567753, respectively.

Crystallographic details for 1: $\mathrm{C}_{12} \mathrm{H}_{8} \mathrm{BClF}_{2} \mathrm{~N}_{2} \mathrm{O}, M=$ 280.46 gmol $^{-1} ; T=293(2) \mathrm{K}$; triclinic space group P-1; $a=$ 7.550(9), $b=11.826(13), c=14.373(16) \AA, \alpha=74.36(3)$, $\beta=88.11(3), \gamma=75.57(2)^{\circ} ; V=1196(2) \AA^{3} ; Z=4 ; 5.31$ $<2 \theta<55.00^{\circ} ; \rho_{\text {calcd }}=1.558 \mathrm{gcm}^{-3} ; \mu=0.335 \mathrm{~mm}^{-1} ; R_{\text {int }}$ $=0.0363 ; R_{1}=0.0454, w R_{2}=0.1260$ for 5406 reflections with $I>2 \sigma(I)$ and 343 parameters; $S=0.887$.

Crystallographic details for 4: $\mathrm{C}_{24} \mathrm{H}_{18} \mathrm{BCl}_{3} \mathrm{~N}_{2} \mathrm{O}, M=$ 396.66 gmol $^{-1} ; T=293(2) \mathrm{K}$; triclinic space group P-1; $a=$ 7.211(8), $b=16.616(16), c=17.872(19) \AA, \alpha=76.23(2)$, $\beta=89.04(3), \gamma=81.27(3)^{\circ} ; V=2055(4) \AA^{3} ; Z=4 ; 5.09$ $<2 \theta<55.05^{\circ} ; \rho_{\text {calcd }}=1.282 \mathrm{gcm}^{-3} ; \mu=0.203 \mathrm{~mm}^{-1} ; R_{\text {int }}$ $=0.0910 ; R_{1}=0.1106, w R_{2}=0.2978$ for 9317 reflections with $I>2 \sigma(I)$ and 523 parameters; $S=1.164$.

Crystallographic details for 6: $\mathrm{C}_{26} \mathrm{H}_{23} \mathrm{BClN}{ }_{3} \mathrm{O}, M=$ $439.73 \mathrm{gmol}^{-1} ; \mathrm{T}=293$ (2) $\mathrm{K}$; monoclinic space group P21/c; $a=13.768(7), b=9.731(4), c=18.160(7) \AA, \alpha=90, \beta=$ 109.581(15), $\gamma=90^{\circ} ; V=2292.3(18) \AA^{3} ; Z=4 ; 5.23<2 \theta$ $<55.04^{\circ} ; \rho_{\text {calcd }}=1.274 \mathrm{gcm}^{-3} ; \mu=0.190 \mathrm{~mm}^{-1} ; R_{\text {int }}=0.1882$; $R_{1}=0.0900, w R_{2}=0.2225$ for 5202 reflections with $I>$ $2 \sigma(I)$ and 289 parameters; $S=1.013$.

\section{Results and discussions}

All pyrazine-boron complexes $\mathbf{1} \sim \mathbf{6}$ demonstrated solidstate fluorescence (Fig. 1, Table 1). The $F_{\max }$ and $\Phi_{\mathrm{f}}$ values of $1 \sim 6$ in the solid state ( $F_{\max }: 524 \sim 672 \mathrm{~nm}, \Phi_{\mathrm{f}}: 0.04 \sim$ $0.29)$ were red-shifted and decreased, respectively, compared to those in $n$-hexane $\left(F_{\max }: 464 \sim 529 \mathrm{~nm}, \Phi_{\mathrm{f}}: 0.13 \sim 0.80\right)$ due to the formation of aggregates. Similar to the results in $n$-hexane, the $F_{\max }$ values of dimethylamino-substituted derivatives $3(672 \mathrm{~nm})$ and $\mathbf{6}(628 \mathrm{~nm})$ and trifluoromethylsubstituted derivatives $\mathbf{2}(531 \mathrm{~nm})$ and $\mathbf{5}(524 \mathrm{~nm})$ showed bathochromic and hypsochromic shifts compared to the non-substituted derivatives $1(542 \mathrm{~nm})$ and $4(536 \mathrm{~nm})$, respectively. However, distinct from the results of $n$-hexane, the $\mathrm{BF}_{2}$ complexes $\mathbf{1} \sim \mathbf{3}$ ( $F_{\text {max }}: 531 \sim 672 \mathrm{~nm}$ ) demonstrated red-shifted $F_{\max }$ values compared to the corresponding $\mathrm{BPh}_{2}$ complexes $4 \sim 6\left(F_{\max }: 524 \sim 628 \mathrm{~nm}\right)$ in the solid state. We attribute this result to the introduction of bulky phenyl groups on the boron atom, which decreased aggregate formation of the $\mathrm{BPh}_{2}$ complexes. Interestingly, synthesized pyrazine monoboron complexes $1 \sim 6\left(F_{\max }: 524 \sim 672 \mathrm{~nm}\right)$ showed red-shifted $F_{\max }$ values compared to the previously reported corresponding pyrimidine monoboron complexes ${ }^{11)}$ ( $F_{\max }: 474 \sim 629 \mathrm{~nm}$ ) in the solid state. This indicates that introduction of pyrazine ring is more effective as compared to that of pyrimidine ring for the spectral red shift of $F_{\max }$ value in the boron complex containing a $\beta$-iminoenolate ligand.

X-ray crystallographic analyses were performed for

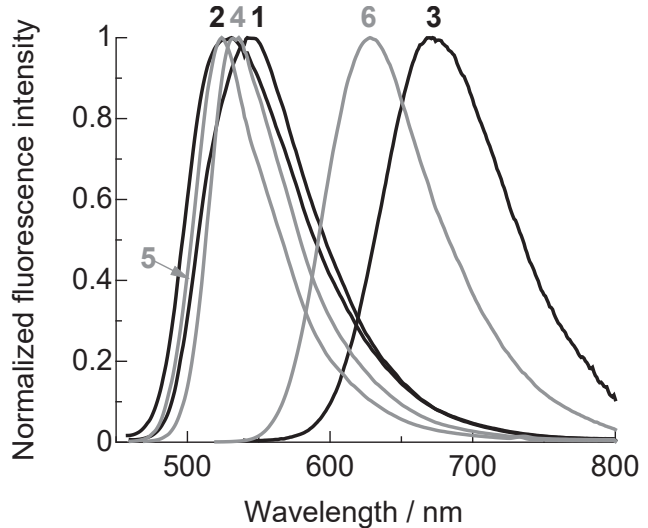

Fig. 1 Normalized fluorescence spectra of $\mathbf{1} \sim \mathbf{6}$ in the solid state.

Table 1 Fluorescence properties of pyrazine boron complexes $^{a}$.

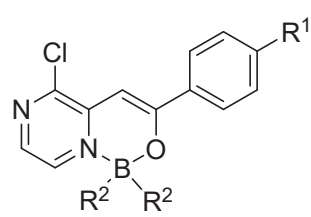

$$
\begin{aligned}
& \text { 1: } R^{1}=H, R^{2}=F \\
& \text { 2: } R^{1}=C F_{3}, R^{2}=F \\
& \text { 3: } R^{1}=N_{2}, R^{2}=F \\
& \text { 4: } R^{1}=H, R^{2}=P h \\
& \text { 5: } R^{1}=C_{3}, R^{2}=P h \\
& \text { 6: } R^{1}=N^{2} e^{2}, R^{2}=P h
\end{aligned}
$$

\begin{tabular}{ccccccc}
\hline \multirow{2}{*}{ Compd } & \multicolumn{3}{c}{ In hexane } & & \multicolumn{2}{c}{ Solid state } \\
\cline { 2 - 3 } \cline { 6 - 6 } & $F_{\max } / \mathrm{nm}$ & $\phi_{\mathrm{f}}$ & & $F_{\max } / \mathrm{nm}$ & $\phi_{\mathrm{f}}$ \\
\hline $\mathbf{1}$ & 446, & 472 & 0.29 & & 542 & 0.13 \\
$\mathbf{2}$ & 438, & 464 & 0.13 & & 531 & 0.12 \\
$\mathbf{3}$ & 506, & 534 & 0.80 & & 672 & 0.04 \\
$\mathbf{4}$ & 505, & 531 & 0.62 & & 536 & 0.29 \\
$\mathbf{5}$ & 502, & 526 & 0.32 & & 524 & 0.26 \\
$\mathbf{6}$ & 529, & 549 & 0.71 & & 628 & 0.13 \\
\hline
\end{tabular}

${ }^{a}$ Measured at a concentration of $1.0 \times 10^{-5} \mathrm{M}$.

complexes $1\left(\Phi_{\mathrm{f}}=0.13\right), 4\left(\Phi_{\mathrm{f}}=0.29\right)$ and $\mathbf{6}\left(\Phi_{\mathrm{f}}=0.13\right)$ to explain differences in the $\Phi_{\mathrm{f}}$ value. In the crystal of $\mathbf{1}$, two crystallographically independent conformers, $\mathbf{1 A}$ and 1 B, were observed (Fig. 2). The conformers 1 A (black molecules) and $\mathbf{1 B}$ (gray molecules) formed independent stacking columns $\mathbf{1} \mathbf{A}^{\prime}$ and $\mathbf{1} \mathbf{B}$ ', respectively, by $\pi-\pi$ interactions (1A': C-C: 3.45 3.69 A, 1B': C-C: 3.50 $3.69 \AA)$. Furthermore, $\mathrm{CH} / \mathrm{F}$ interactions were observed between 1A' and 1 B' (C-F: 3.16 3.40 $\AA$ ). Therefore, the relatively low $\Phi_{\mathrm{f}}$ value of 1 was attributed to the strong and consecutive $\pi-\pi$ interactions.

In the case of $\mathbf{4}$, similar to the corresponding $\mathrm{BF}_{2}$ complex 1, two independent crystallographic conformers $4 \mathrm{~A}$ and $\mathbf{4 B}$ were observed (Fig. 3). Each 4A (black molecules) and 4B (gray molecules) formed independent stacking columns by the $\pi-\pi$ interactions (C-C: $3.53 \sim 3.68 \AA$ in $\mathbf{4 A}, 3.47 \sim 3.68 \AA$ in $4 B$ ). The stacking column of $\mathbf{4 B}$ showed $\mathrm{CH} / \pi$ interactions (C9-C 8': $3.65 \AA$ ) with that of the neighboring stacking column of $\mathbf{4 A}$. The neighboring stacking column of $4 \mathrm{~A}$ also showed $\mathrm{CH} / \pi$ interactions $(\mathrm{C} 10-\mathrm{C} 16: 3.67 \AA)$ with the neighboring stacking column of $\mathbf{4 A}$. The $\mathrm{CH} / \pi$ interactions (C9-C8': $3.65 \AA$ ) also attached the stacking column of $4 \mathrm{~A}$ to the neighboring stacking column of $4 \mathrm{~B}$. Consequently, 
(a)

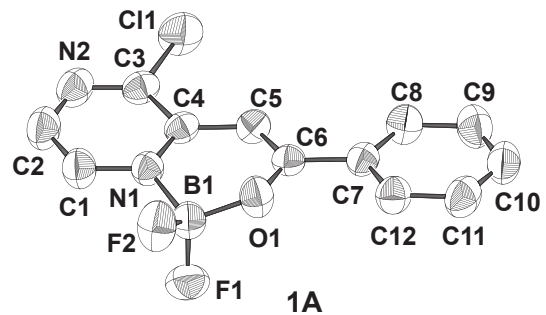

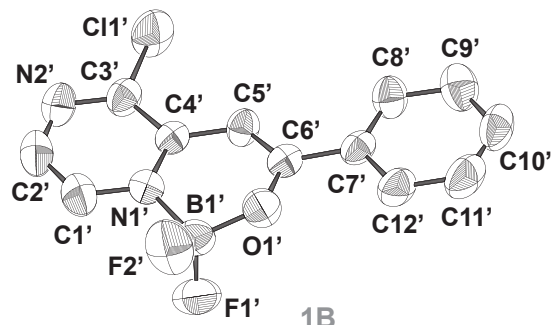

(b)

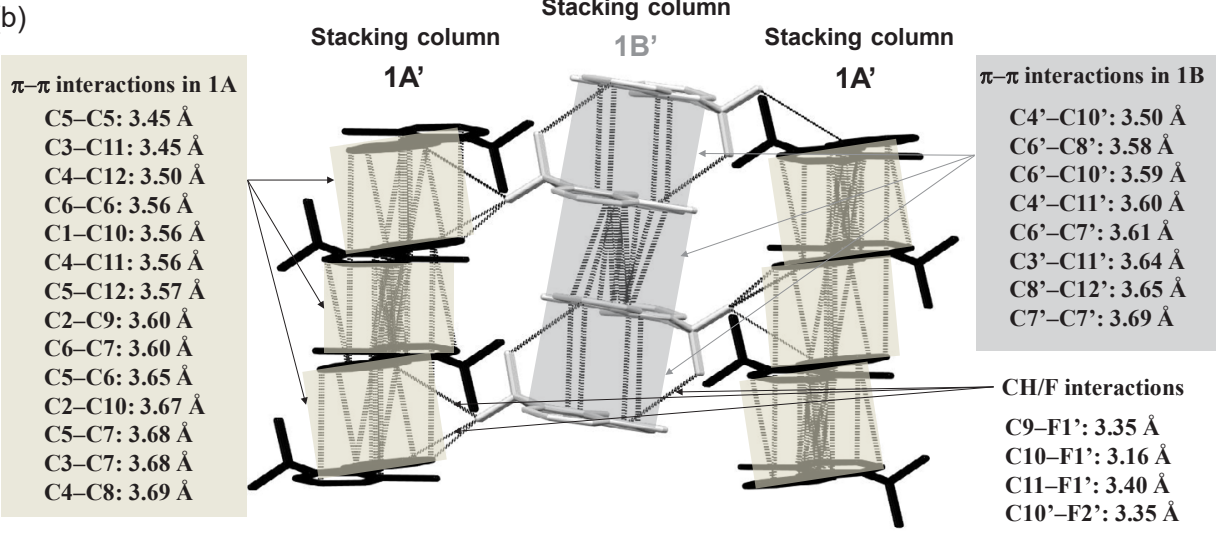

Fig. 2 (a) ORTEP view of $\mathbf{1}$. Hydrogen atoms were omitted for clarity. (b) Molecular packing and list of intermolecular interactions of $\mathbf{1 .}$

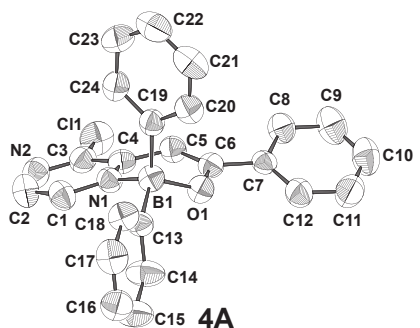

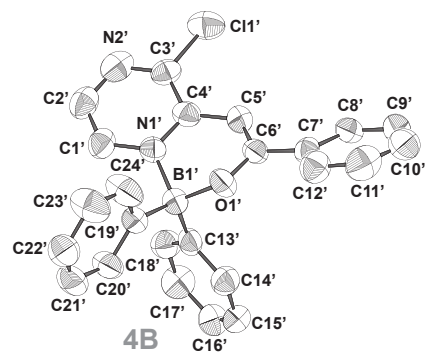

Stacking sequence $\mathbf{4 S}$

(b)

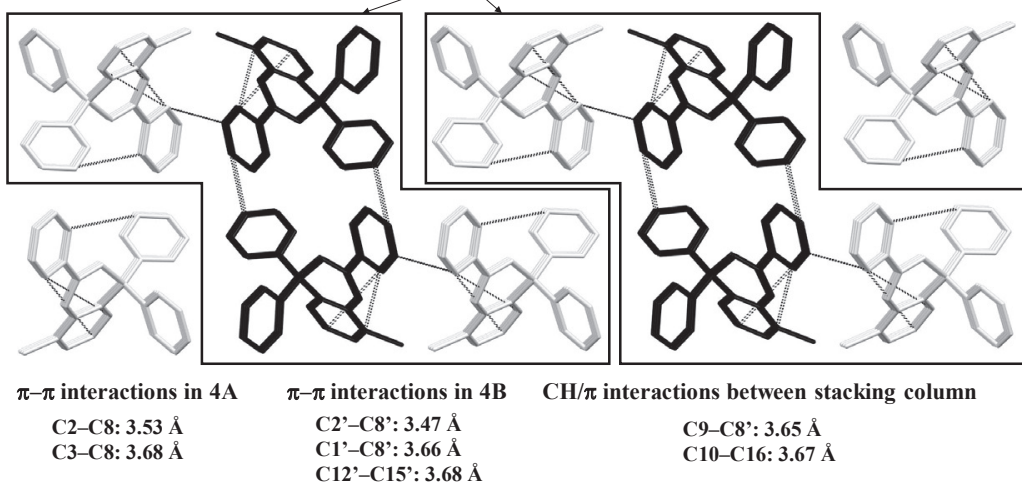

Fig. 3 (a) ORTEP view of 4 . Hydrogen atoms were omitted for clarity. (b) Molecular packing and list of intermolecular interactions of 4.

the stacking sequence $\mathbf{4 S}$ was formed in the neighboring two stacking columns of $\mathbf{4 B}$ and two stacking columns of $\mathbf{4 A}$. The molecular packing of $\mathbf{4}$ consisted of the repeated structure of 4S. No interaction between the adjacent stacking sequences $4 \mathrm{~S}$ was observed. Compared to $\mathrm{BF}_{2}$ complex $1, \mathrm{BPh}_{2}$ complex 4 showed weaker intermolecular interactions: Complex $\mathbf{1}$ showed many strong $\pi-\pi$ interactions in the stacking column; however, 4 showed less interaction than $\mathbf{1}$. Because of the weaker interactions, $\mathrm{BPh}_{2}$ complex $4\left(\Phi_{\mathrm{f}}=0.29\right)$ exhibited a higher $\Phi_{\mathrm{f}}$ than $\mathrm{BF}_{2}$ complex $1\left(\Phi_{\mathrm{f}}=0.13\right)$.

In the crystal packing of dimethylamino-substituted $\mathrm{BPh}_{2}$ complex $\mathbf{6}$, the molecules depicted in black and gray formed dimers by the $\pi-\pi$ interactions (C-C: $3.65 \AA$ ) (Fig. 4). Furthermore, the $\mathrm{CH} / \pi$ interactions were observed for each dimer (C-C: $3.68 \AA$ ). Consequently, consecutive intermolecular interactions were formed throughout the 
(a)

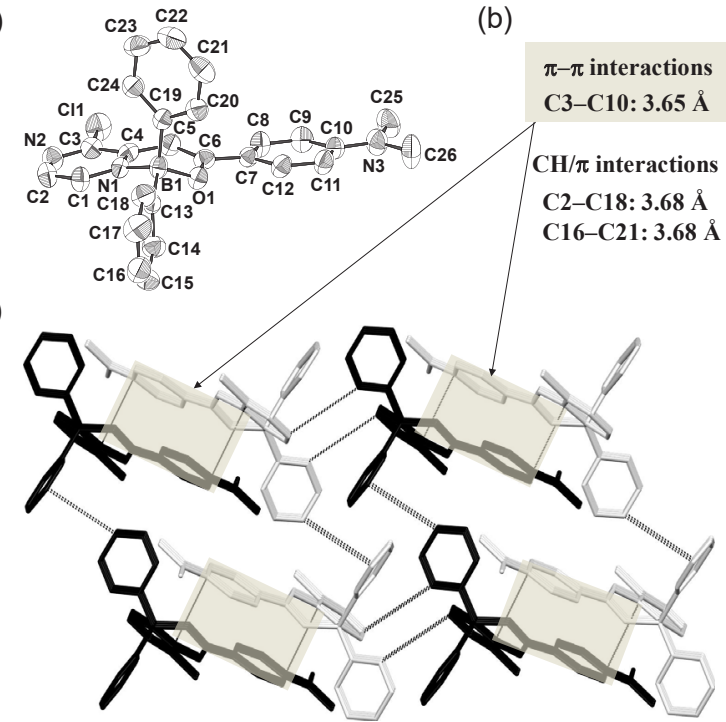

Fig. 4 (a) ORTEP view of $\mathbf{6}$. Hydrogen atoms were omitted for clarity. (b) List of intermolecular interactions of $\mathbf{6}$. (c) Molecular packing of $\mathbf{6}$.

molecule. Similar to boron complex 4 , dimethylamino derivative $\mathbf{6}$ had weaker intermolecular interactions compared to boron complex 1 . Despite the weaker intermolecular interactions, the $\Phi_{\mathrm{f}}$ value of $\mathbf{6}\left(\Phi_{\mathrm{f}}=0.13\right)$ was same as that of $1\left(\Phi_{\mathrm{f}}=0.13\right)$. According to the energy gap law ${ }^{16)}$, the nonradiative rate constant $\left(k_{\mathrm{nr}}\right)$ should increase with decreasing emission energy which is inversely proportional the $F_{\max }$ value. Since a red-shift of $F_{\max }$ was expected to promote the nonradiative processes, the red-shifted $F_{\max }$ values of $\mathbf{6}$ and $\mathbf{3}$ compared to the other complexes were considered to decrease the $\Phi_{\mathrm{f}}$ values.

\section{Conclusions}

Pyrazine monoboron complexes exhibited solid-state fluorescence. The maximum fluorescence wavelengths of dimethylamino $\left(F_{\max }: 628 \sim 672 \mathrm{~nm}\right)$ and trifluoromethyl $\left(F_{\max }: 524 \sim 531 \mathrm{~nm}\right)$ substituted derivatives were red- shifted and blue-shifted, respectively, compared to the non-substituted derivatives ( $\left.F_{\max }: 536 \sim 542 \mathrm{~nm}\right)$. When considering the crystal packing, although the $\mathrm{BF}_{2}$ complexes formed consecutive $\pi-\pi$ interactions through $\mathrm{CH} / \mathrm{F}$ interactions, no consecutive interactions were observed in $\mathrm{BPh}_{2}$ complexes. Thus, the $\mathrm{BPh}_{2}$ complexes exhibited higher fluorescence quantum yields $\left(\Phi_{\mathrm{f}}: 0.13 \sim 0.29\right)$ compared to the corresponding $\mathrm{BF}_{2}$ complexes $\left(\Phi_{\mathrm{f}}: 0.04 \sim 0.13\right)$.

\section{Acknowledgements}

This work was supported by JSPS KAKENHI Grant Number JP19K05628.

\section{References}

1) Z. Chang, Y. Jiang, B. He, J. Chen, Z. Yang, P. Lu, H. S. Kwok, Z. Zhao, H. Qiu, B. Z. Tang: Chem. Commun., 49, 594 (2013).

2) A. Costela, I. García-Morenoa, R. Sastreb: Phys. Chem. Chem. Phys., 5, 4745 (2003)

3) A. Dadvand, W.-H. Sun, A. G. Moiseev, F. Bélanger-Gariépy, F. Rosei, H. Meng, D. F. Perepichka: J. Mater. Chem. C, 1, 2817 (2013).

4) J. Mei, N. L. C. Leung, R. T. K. Kwok, J. W. Y. Lam, B. Z. Tang: Chem. Rev., 115, 11718 (2015).

5) C. Kitamura, Y. Abe, T. Ohara, A. Yoneda, T. Kawase, T. Kobayashi, H. Naito, T. Komatsu: Chem. Eur. J., 16, 890 (2010).

6) K. Shirai, M. Matsuoka, K. Fukunishi: Dyes Pigm., 42, 95 (1999).

7) S.-Y. Park, M. Ebihara, Y. Kubota, K. Funabiki, M. Matsui: Dyes Pigm., 82, 258 (2009).

8) D. Frath, J. Massue, G. Ulrich, R. Ziessel: Angew. Chem. Int. Ed., 53, 2290 (2014).

9) A. Loudet, K. Burgess: Chem. Rev., 107, 4891 (2007).

10) Y. Kubota, K. Kasatani, T. Niwa, H. Sato, K. Funabiki, M. Matsui: Chem. Eur. J., 22, 1816 (2016).

11) Y. Kubota, H. Kasatani, K. Takai, K. Funabiki, M. Matsui: Dalton Trans., 44, 3326 (2015)

12) Y. Kubota, S. Tanaka, K. Funabiki, M. Matsui: Org. Lett., 14, 4682 (2012).

13) Y. Kubota, H. Hara, S. Tanaka, K. Funabiki, M. Matsui: Org. Lett., 13, 6544 (2011).

14) Y. Kubota, J. Uehara, K. Funabiki, M. Ebihara, M. Matsui: Tetrahedron. Lett., 51, 6195 (2010).

15) Y. Kubota, Y. Sakuma, K. Funabiki, M. Matsui: J. Phys. Chem. A, 118, 8717 (2014)

16) W. Siebrand: J. Chem. Phys., 46, 440 (1967).

\title{
ピラジンホウ素錯体の結晶構造と量子収率との相関について
}

\author{
篞田裕大*,†・配島優生*・船曳一正* ·松居正樹* \\ *岐阜大学工学部化学・生命工学科 岐阜県岐阜市柳戸1-1（テ 501-1193） \\ $\dagger$ Corresponding Author, E-mail: kubota@gifu-u.ac.jp
}

(2020年5月26日受付, 2020年8月 17 日受理)

要旨

ピラジン単核ホウ素錯体1 6において結晶のパッキングと蛍光量子収率 $\Phi_{\mathrm{f}}$ との相関について調べた。フェニル誘導体 4 〜 $6\left(F_{\max }\right.$ : $\left.524 \sim 628 \mathrm{~nm}, \quad \Phi_{\mathrm{f}}: 0.13 \sim 0.29\right)$ は対応するフッ素誘導体1 3 $\left(F_{\max }: 531 \sim 672 \mathrm{~nm}, \quad \Phi_{\mathrm{f}}: 0.04 \sim 0.13\right)$ に比べて弱い分子間相互作用 が観測された。このため最大蛍光波長 $F_{\max }$ は短波長化し，高い $\Phi_{\mathrm{f}}$ 值を示した。ジメチルアミノ基を有するフェニル誘導体6は無置換体 フッ素誘導体1よりも弱い分子間相互作用を示したにもかかわらず，6と1の $\Phi_{\mathrm{f}}$ 值は同じであった。これは6の $F_{\max }$ が長波長化し無輻射 失活が促進されたためだと考えられる。 